\title{
Influence of starch digestion in the large intestine of sheep on caecal fermentation, caecal microflora and faecal nitrogen excretion
}

\author{
By E. R. ØRSKOV, C. FRASER, V. C. MASON AND S. O. MANN \\ Rowett Research Institute, Bucksburn, Aberdeen $A B 2{ }_{9} S B$
}

(Received ro October 1969-Accepted 29 February 1970)

\begin{abstract}
I. The concentrations of volatile fatty acids (VFA) in the rumen and caecum were compared when sheep were given barley or dried grass. The molar proportions of VFA in the caecum resembled those in the rumen except that the proportions of isobutyric and isovaleric acids were higher in caecal than in rumen fluid indicating an extensive breakdown of protein during fermentation in the caecum.

2. The capacity for starch digestion in the large intestine was studied in two sheep receiving dried grass. Starch was infused into the caecum, the amount given increasing by daily increments of $20 \mathrm{~g}$ until $300 \mathrm{~g}$ daily were infused. Infused starch in excess of $138 \mathrm{~g}$ daily largely appeared in the faeces, indicating a limited but substantial capacity for starch fermentation in the large intestine. The infusion caused a marked increase in the molar proportion of butyric acid.

3. Determinations made with a single sheep showed that the infusion of starch into the caecum caused large changes in the microflora, and species similar to Butyrivibrio became prevalent. The viable count on a starch medium was increased by $83 \%$ by starch infusion.

4. The infusions of starch increased the excretion of nitrogen in the faeces from 5.8 to $9.0 \mathrm{~g}$ daily. Using a fractionation procedure it was shown that when $100 \mathrm{~g}$ of starch were fermented in the large intestine the 'bacterial and endogenous debris' nitrogen increased by about $\mathrm{I} \cdot \mathrm{O} \mathrm{g}$. When starch was given orally to two sheep the increase in this fraction was about $0.4 \mathrm{~g}$ nitrogen/ roo $\mathrm{g}$ starch digested.

5. It is suggested that dietary factors that cause changes in the site of fermentation from the rumen to the caecum will render less microbial nitrogen available to the host animal per unit of carbohydrate fermented and decrease the apparent digestibility of nitrogen.
\end{abstract}

In recent experiments on sheep (Ørskov, Fraser \& Kay, I969) it was found that, when diets rich in ground and cracked maize were given, substantial quantities of dietary starch escaped fermentation in the rumen. It was also observed that the starch that escaped rumen fermentation was not always fully digested in the small intestine but passed through the terminal ileum to be subsequently fermented in the large intestine. The effects of starch on fermentation in the caecum appeared to be similar to its effects in the rumen (see Blaxter, 1967 ) in that the proportion of acetic acid in the caecal fluid fell while that of both propionic and butyric acid rose. Since carbohydrate is the main energy source for anaerobic microbial growth it was postulated (Ørskov, Fraser \& Kay, 1969) that, while a difference in site of fermentation of carbohydrate may not influence the energy availability to the host animal, it would probably influence the amount of microbial protein available per unit of carbohydrate fermented. This is because micro-organisms produced in the rumen are digested in the abomasum whereas no digestion of microbes has been shown to occur in the caecum and large intestine and absorption of amino acids from that site is negligible (Wiseman, 1968). The whole of the micro-organisms produced would, therefore, appear in the faeces. 
An increased fermentation of carbohydrate in the caecum would, thus, be expected to raise the microbial nitrogen excretion and perhaps also cause increases in the total faecal nitrogen excretion.

The experiments reported here were conducted to determine the influence of diet on the type of fermentation in the caecum; to investigate the capacity for starch digestion in the caecum and to observe the influence of starch fermentation on nitrogen excretion. The influence of starch fermentation on the caecal microflora was also investigated. A preliminary account of this work has been published (Ørskov \& Foot, 1969).

\section{EXPERIMENTAL}

\section{Animals}

Expt I. Eight 9-month-old Suffolk $\times$ North Country Cheviot sheep weighing approximately $50 \mathrm{~kg}$ were used. They had previously been used in an experiment to determine the voluntary intake of barley and roots (Ørskov, Andrews \& Gill, I969).

Expt 2. Two mature castrated male Cheviot $\times$ Scottish Blackface sheep were used. Each was fitted with a cannula in the terminal ileum about $25 \mathrm{~cm}$ anterior to the ileo-caecal junction; in addition one had a cannula in the tip of the caecum and the other had a cannula in the sigmoid colon.

Expt 3. A 9-month-old Suffolk $\times$ Scottish Half-bred female sheep was used. It was fitted with cannulas in the terminal ileum and in the abomasum.

\section{Experimental procedure}

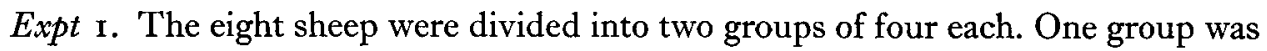
offered rolled barley to appetite and the other was given chopped dried grass to appetite. Both groups received the diets for a period of $8 \mathrm{~d}$. The animals receiving rolled barley ate an average of $1030 \mathrm{~g}$ of dry matter/d while those receiving dried grass ate an average of $800 \mathrm{~g}$ dry matter. At the end of the $8 \mathrm{~d}$ the animals were slaughtered within $\mathrm{I} h$ of being taken away from the feed. Samples of rumen and caecal contents were obtained and strained through cheese-cloth. To stop fermentation, $0.5 \mathrm{ml}$ of a saturated solution of $\mathrm{HgCl}_{2}$ was added to $25 \mathrm{ml}$ of the filtrate.

Expt 2. Each of two sheep received daily $900 \mathrm{~g}$ of a pelleted dried grass $(15.5 \%$ crude protein on a dry-matter basis) from a continuous feeding device (Sutherland, Gupta, Reid \& Murray, 1963). They were kept in metabolism cages and given free access to water. Faeces were collected daily and dried to constant weight at $100^{\circ}$ and, in addition, rectal samples were obtained thrice daily and stored at $-4^{\circ}$.

A catheter was introduced through the ileal cannula so that its tip lay just within the caecum. For the ist 3 days a saline solution $(2 \mathrm{l}$ of $0.8 \% \mathrm{NaCl}$ ) was infused through the catheter. A suspension of raw maize starch was then added to the infusate, increasing in amount by $20 \mathrm{~g} / \mathrm{d}$ (17.3 $\mathrm{g}$ dry matter) to a maximum infusion of $300 \mathrm{~g} / \mathrm{d}$ after $\mathrm{I}_{5} \mathrm{~d}$. The infusion was made with a Watson-Marlow peristaltic infusion pump. The reservoir of infusate was kept stirred at a temperature of $50^{\circ}$. At the end of the starch infusion, saline only was infused for a further $3 \mathrm{~d}$.

Every 2nd day a sample was obtained from the large intestine, via the cannulas, 
either from the colon (sheep A) or from the caecum (sheep B). It proved difficult to obtain samples from sheep $A$ and on occasions no samples were obtained or they were too small for analysis. The samples were stored at $-4^{\circ}$ until they were prepared for volatile fatty acid (VFA) analysis. The daily faeces samples were analysed for starch and nitrogen. During the preliminary period, and when $300 \mathrm{~g}$ starch were infused, samples of caecal contents from sheep B were obtained for microbial examination. With both sheep, faecal samples were obtained for VFA analysis and fractionation of faecal nitrogen during the preliminary periods and when $300 \mathrm{~g}$ starch were infused.

When the starch-infusion trial was completed, sheep B was given $23 \circ \mathrm{g}$ of maize starch daily for $17 \mathrm{~d}$ mixed with the dried grass pellets on the continuous feeding belt; faecal collection was made for the last $7 \mathrm{~d}$. A third period of $\mathrm{x} 0 \mathrm{~d}$ followed during which only the dried grass diet was given and the faeces were collected for the last $7 \mathrm{~d}$ of that period. During the latter trial the daily faeces output was stored at $x^{\circ}$ and pooled for the collection period. Samples of the pooled faeces were obtained for drymatter and nitrogen determinations and also for fractionation of the faecal nitrogen.

Expt 3. A further trial was conducted to provide more information on the effect of caecal or oral administrations of starch on the output and composition of faecal nitrogen and also on urinary nitrogen. The sheep received daily a basal ration of $900 \mathrm{~g}$ of pelleted dried grass which was given in two equal portions at 09.00 hours and 17.30 hours. The pelleted grass contained $9.9 \%$ crude protein in the dry matter. The experimental procedure is described below.

\begin{tabular}{|c|c|c|c|}
\hline $\begin{array}{l}\text { Period } \\
\text { no. }\end{array}$ & $\begin{array}{l}\text { Length of } \\
\text { period (d) }\end{array}$ & $\begin{array}{l}\text { Days for } \\
\text { collection } \\
\text { of faeces } \\
\text { and urine }\end{array}$ & Treatment \\
\hline I & $\mathrm{I} \rightarrow \mathrm{I} 7$ & $\mathrm{II}-\mathrm{I} 7$ & Basal ration $+200 \mathrm{~g}$ maize starch \\
\hline 2 & $x 8-30$ & $24-30$ & Basal ration \\
\hline 3 & $3 I-44$ & $37-44$ & $\begin{array}{l}\text { Basal ration }+ \text { I } 7 \mathrm{~g} \text { maize starch infused } \\
\text { via terminal ileum }\end{array}$ \\
\hline 4 & $45-56$ & $50-56$ & Basal ration \\
\hline
\end{tabular}

During the infusion period the starch was prepared by boiling it for $10 \mathrm{~min}$ to give a transparent gel to ease infusion. The gel was kept at $50^{\circ}$ in a water-bath and infused with a Sigma Motor infusion pump. As in Expt 2, in which raw starch was used, the gel was prepared in saline $(0.8 \% \mathrm{NaCl})$. The urine was collected into a solution of formalin and acetic acid to give a final formalin concentration of at least $\mathrm{r} \%$ and a $\mathrm{pH}$ of less than 5 .

\section{Analytical procedures}

Nitrogen was determined by the macro-Kjeldahl method of The Association of Official Agricultural Chemists (1960) with mercuric oxide as catalyst. The ammonia was estimated colorimetrically as the indophenol blue complex in a Technicon AutoAnalyzer.

The starch was determined as $\alpha$-linked glucose polymers according to a method developed by MacRae \& Armstrong (1966); after gelatinization and incubation with $\alpha$-glucosidase the glucose was determined by the glucose oxidase method. Samples of 
rumen content were strained and $5 \mathrm{ml}$ were acidified with $\mathrm{I} \mathrm{ml}$ of a $25 \%$ metaphosphoric acid solution. Caecal contents and faeces were first suspended in an equal weight of water and $5 \mathrm{ml}$ were acidified as described above. After centrifugation the VFA were determined on the supernatant fluid by gas-liquid chromatography with flame ionization detector (Pye 104). The VFA concentration in some faeces samples was determined on the supernatant fluid using a Markham apparatus.

Fractionation of faecal nitrogen. The faecal nitrogen compounds were fractionated according to a method described by Mason (I969). The undigested dietary nitrogen (UDN) was estimated as the nitrogen resistant to a modification of the acid detergent extraction described by Van Soest ( 1963 ). This fraction was used to estimate the true digestibility of the nitrogen. The bacterial and endogenous debris nitrogen (BEDN) was estimated as the nitrogen in the fraction isolated from suspension by centrifugation at $20000 \mathrm{~g}$ for $30 \mathrm{~min}$ (less the UDN). The water-soluble nitrogen (WSN) was the nitrogen in the supernatant fluid and was estimated as the difference between total nitrogen and UDN + BEDN.

Examination of caecal microflora. Estimations of the numbers of viable bacteria were made using the anaerobic media described by Kurihara, Eadie, Hobson \& Mann (I968) whose techniques were based on those of Hungate (1950). These workers employed the techniques for the isolation of anaerobic and facultatively anaerobic bacteria from the rumen using two different media, a starch-containing medium, and a multiple carbohydrate medium (M 8). Gram-positive rods growing in the anaerobic roll-tube cultures were subcultured on to the lactobacillus medium of Rogosa, Mitchell \& Wiseman (I95 I). All Gram-positive, non-sporing, catalase-negative rods capable of growing on this selective medium were recorded as lactobacilli.

Films from representative colonies growing in the roll-tube cultures inoculated with the higher dilutions of caecal contents were stained by Gram's method and an assessment was made of the principal morphological forms (Mann, 1970).

RESULTS

Expt $\mathrm{x}$. The proportions of VFA found in rumen and caecal contents are given in Table I.

The proportion of VFA in the contents differed between diets. Significantly more acetic acid and less butyric acid $(P<0.01)$ were found in both rumen and caecal contents when dried grass was given than when barley was given. Diet did not affect the proportion of propionic acid found in the rumen, but in the caecum a significantly higher proportion was found when barley was given $(P<0.05)$. The proportion of acetic acid was on average higher by 2 molar percentage units in the caecum than in the rumen though this difference was not significant.

Expt 2: starch infusion. The infusion of starch into the caecum did not influence the intake of the basal diet. When more than $\mathrm{r}^{8} \mathrm{~g}$ of starch were infused the faeces became very soft and unpelleted but this caused no apparent discomfort to the animals.

The effect of the infusion on the dry matter excreted in the faeces is given graphi- 
cally in Fig. I. To smooth the curve of day-to-day variation in faecal dry-matter output, each daily value, when starch infusion was increased, was calculated as the mean of the 2 previous days, the day of sampling and the 2 subsequent days. With both sheep the infusion of starch increased the dry-matter output, and when the infusion was terminated the output of dry matter soon fell to reach pre-infusion levels.

The effect of caecal starch infusion on the excretion of starch in the faeces is illustrated in Fig. 2. The starch excreted was calculated from the values for dry matter

Table I. Mean values (\%) for the molar proportions of volatile fatty acids in rumen and caecal fluid

(Values are means for four sheep receiving dried grass or rolled barley ad lib.)

\begin{tabular}{|c|c|c|c|c|c|c|c|c|}
\hline Diet & Site & $\begin{array}{l}\text { Acetic } \\
\text { acid }\end{array}$ & $\begin{array}{l}\text { Propionic } \\
\text { acid }\end{array}$ & $\begin{array}{l}\text { Iso- } \\
\text { butyric } \\
\text { acid }\end{array}$ & $\begin{array}{l}\text { Butyric } \\
\text { acid }\end{array}$ & $\begin{array}{c}\text { Iso- } \\
\text { valeric } \\
\text { acid }\end{array}$ & $\begin{array}{c}\text { Valeric } \\
\text { acid }\end{array}$ & $\begin{array}{l}\text { Caproic } \\
\text { acid }\end{array}$ \\
\hline Dried grass & Rumen & $68 \cdot 6$ & $20 \cdot 2$ & $2 \cdot 5$ & 6.0 & $2 \cdot 0$ & 0.8 & - \\
\hline Dried grass & Caecum & $70 \cdot 2$ & 15.5 & $2 \cdot 6$ & $6 \cdot 0$ & 3.5 & $2 \cdot I$ & - \\
\hline Barley & Rumen & $53 \cdot 6$ & $20 \cdot 6$ & $x \cdot 7$ & $16 \cdot 2$ & I' 4 & $5 \cdot 4$ & $I \cdot I$ \\
\hline Barley & Caecum & $55^{\cdot 8}$ & 19.9 & $4 \cdot 5$ & 12.7 & 4.5 & $2 \cdot 7$ & - \\
\hline $\begin{array}{l}\text { SE of treatment } \\
\text { differences }\end{array}$ & & $4^{\circ} 0$ & $2 \cdot 0$ & 0.9 & $2 \cdot 2$ & 0.7 & 0.7 & - \\
\hline
\end{tabular}

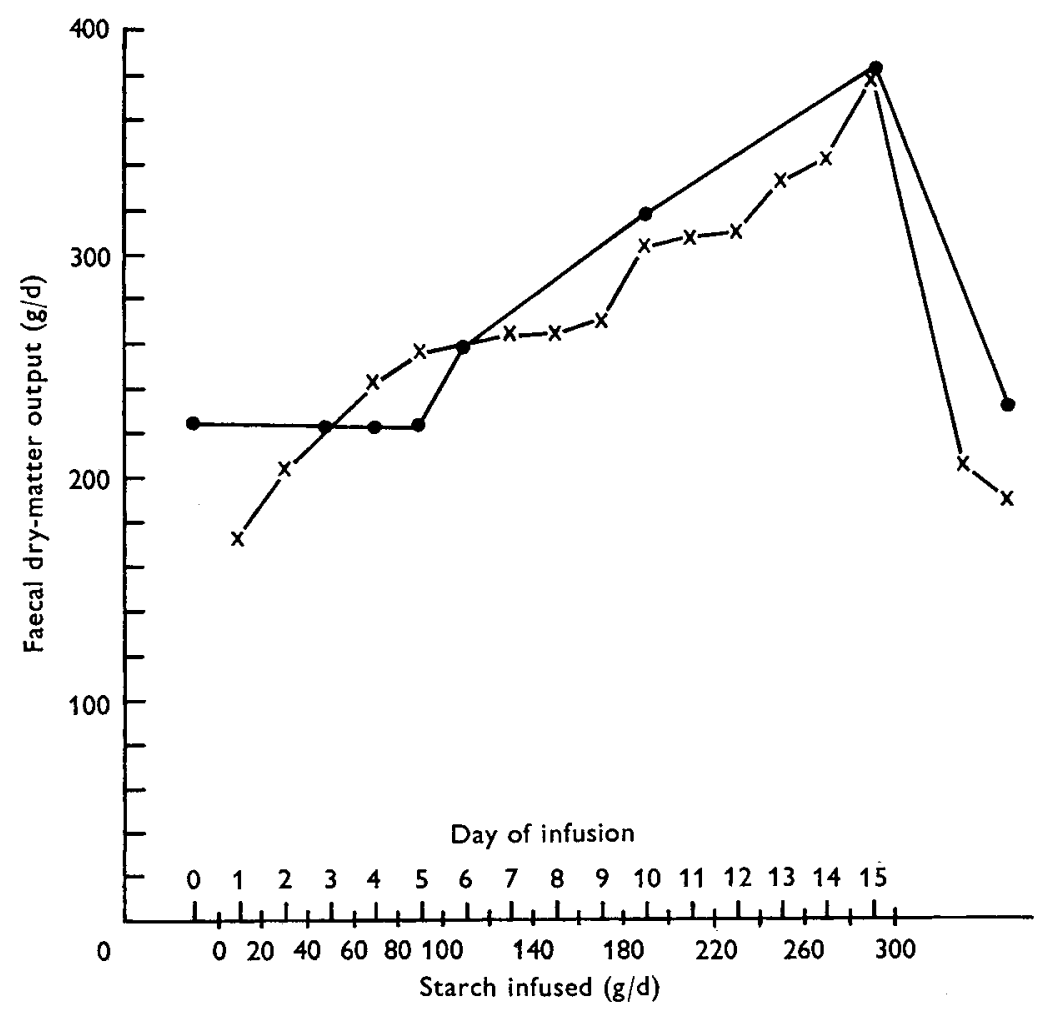

Fig. r. Influence of caecal starch infusion on daily faecal dry-matter output of sheep A $(x-x)$ and sheep $B(-)$ ) when they received a basal diet of $900 \mathrm{~g} / \mathrm{d}$ of dried grass pellets. 
referred to above. It is clear that with both sheep there was a limit to the capacity for starch digestion in the large intestine since most of the increment given in excess of $138 \mathrm{~g}$ daily appeared in the faeces. When the infusion was terminated the values immediately returned to the pre-infusion levels.

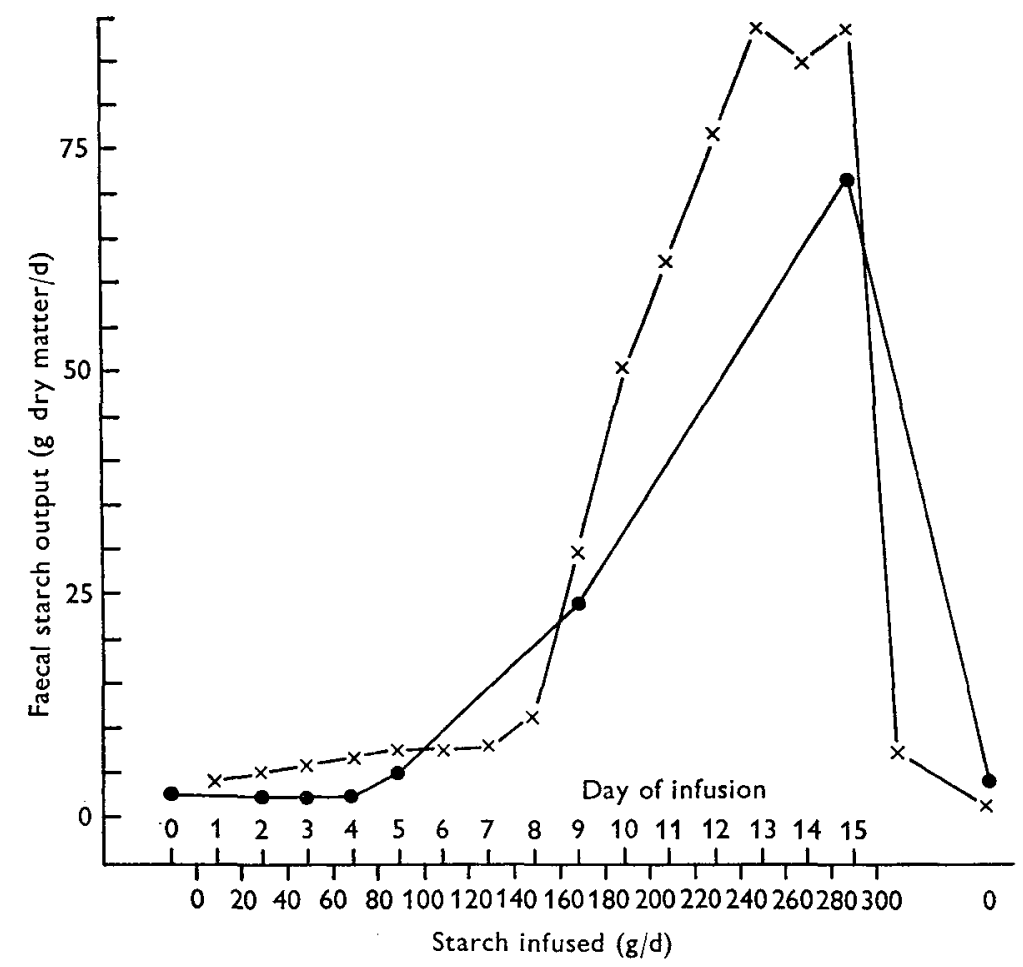

Fig. 2. Influence of caecal starch infusion on daily faecal output of starch (g dry matter) of sheep $A(x-x)$ and sheep $B(-)$ when they received a basal diet of $900 \mathrm{~g} / \mathrm{d}$ of dried grass pellets.

The influence of starch infusion on the excretion of total nitrogen in the faeces is given in Fig. 3. The infusion of starch increased the excretion of nitrogen substantially. With sheep A the faecal nitrogen increased from $5 \cdot 0$ to $9 \cdot 1 \mathrm{~g}$ and with sheep $B$ from 6.6 to $10.0 \mathrm{~g} / \mathrm{d}$. With sheep $A$ the nitrogen output increased rapidly and stayed relatively constant and seemed to be related to the starch disappearance (Fig. 2) while with sheep $B$ the increase seemed to be more nearly linear.

Table 2 shows the proportions of VFA found in the large intestine and in the faeces; values found when only saline was infused are compared with those found when $300 \mathrm{~g}$ of starch were infused. The starch infusion lowered the proportion of acetic acid in both the colon and caecum, but the most marked effect of the infusion was to raise the proportion of butyric acid about threefold in the colon and caecum and also in the faeces. The proportions of iso-acids were high both in the large intestine and in the faeces in comparison with the rumen values given in Table $I$.

The total amount of VFA in the moist faeces voided when $300 \mathrm{~g}$ starch were 


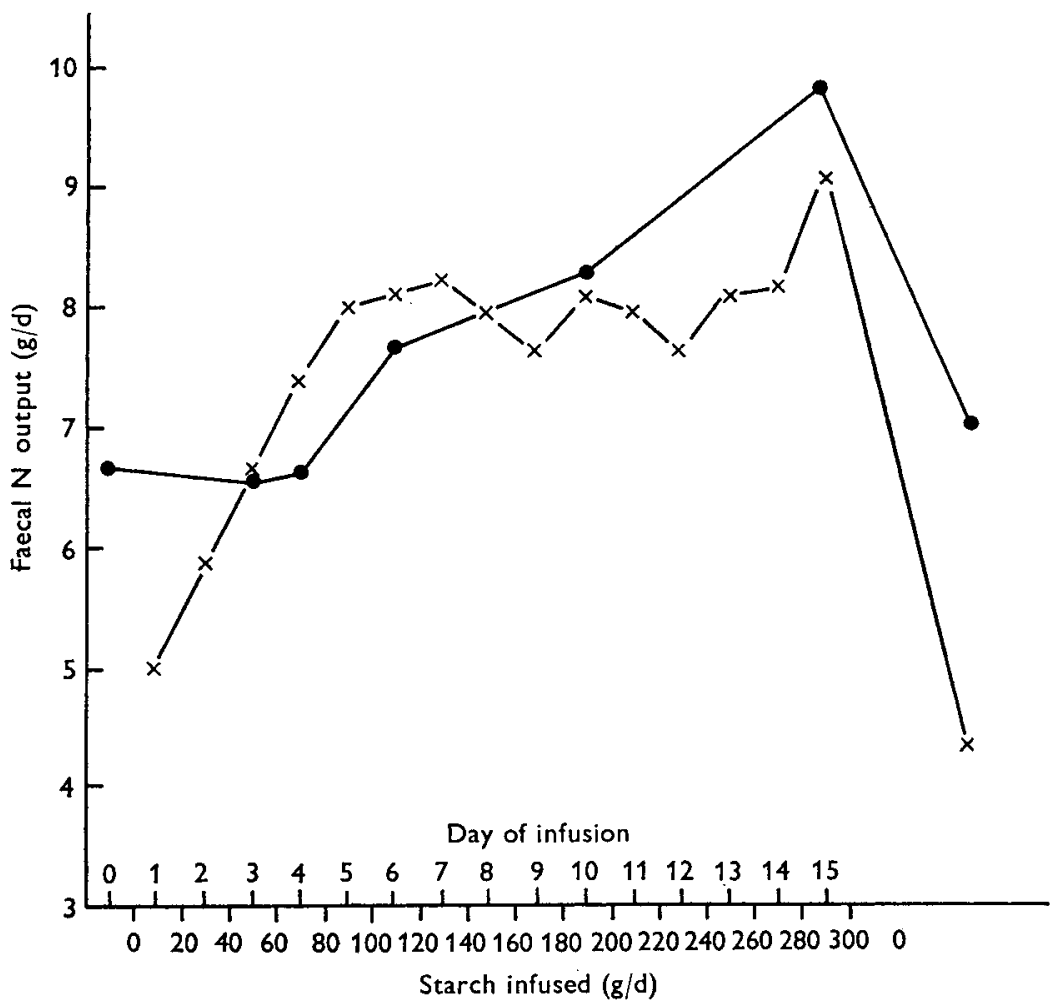

Fig. 3. Influence of caecal starch infusion on daily faecal output of nitrogen of sheep $A$ $(x-x)$ and sheep $B(-)$ when they received a basal diet of $900 \mathrm{~g} / \mathrm{d}$ of dried grass pellets. Infusion was terminated on day 15 .

Table 2. Proportions of volatile fatty acids (VFA) (moles/100 moles) in the large intestine or faeces when no starch was infused or when $300 \mathrm{~g}$ of starch were infused into the caecum in two sheep

\begin{tabular}{|c|c|c|c|c|c|c|c|c|c|}
\hline Sheep & Site & $\begin{array}{l}\text { Starch } \\
\text { in- } \\
\text { fused }\end{array}$ & $\begin{array}{l}\text { Acetic } \\
\text { acid }\end{array}$ & $\begin{array}{l}\text { Propionic } \\
\text { acid }\end{array}$ & $\begin{array}{l}\text { Iso- } \\
\text { butyric } \\
\text { acid }\end{array}$ & $\begin{array}{c}\text { Butyric } \\
\text { acid }\end{array}$ & $\begin{array}{l}\text { Iso- } \\
\text { valeric } \\
\text { acid }\end{array}$ & $\begin{array}{c}\text { Valeric } \\
\text { acid }\end{array}$ & $\begin{array}{c}\text { Total } \\
\text { VFA } \\
\text { concen- } \\
\text { tration } \\
\text { (m-moles/l } \\
\text { faecal } \\
\text { water) }\end{array}$ \\
\hline A & Colon & $\begin{array}{l}\text { None } \\
300 \mathrm{~g}\end{array}$ & $\begin{array}{l}66 \cdot 0 \\
61 \cdot 4\end{array}$ & $\begin{array}{l}15.4 \\
10.6\end{array}$ & $\begin{array}{l}4 \cdot 4 \\
3 \cdot 2\end{array}$ & $\begin{array}{r}6 \cdot 6 \\
20 \cdot 6\end{array}$ & $\begin{array}{l}3 \cdot 8 \\
2 \cdot 5\end{array}$ & $\begin{array}{l}3.9 \\
\mathrm{I} \cdot 7\end{array}$ & - \\
\hline B & Caecum & $\begin{array}{l}\text { None } \\
300 \mathrm{~g}\end{array}$ & $\begin{array}{l}77 \cdot x \\
65 \cdot 1\end{array}$ & $\begin{array}{l}7.8 \\
9.8\end{array}$ & $\begin{array}{l}6 \cdot 3 \\
4 \cdot 5\end{array}$ & $\begin{array}{r}4.7 \\
14.8\end{array}$ & $\begin{array}{l}4 \cdot 2 \\
4 \cdot 1\end{array}$ & $\overline{1.7}$ & - \\
\hline $\mathbf{A}$ & Faeces & $\begin{array}{l}\text { None } \\
300 \mathrm{~g}\end{array}$ & $\begin{array}{l}68 \cdot 5 \\
70 \cdot 2\end{array}$ & $\begin{array}{r}20 \cdot 5 \\
5 \cdot 1\end{array}$ & $\begin{array}{l}2.9 \\
3.9\end{array}$ & $\begin{array}{r}6 \cdot 7 \\
19 \cdot 5\end{array}$ & $\begin{array}{l}r \cdot 5 \\
r \cdot 3\end{array}$ & - & $\begin{array}{r}64 \cdot 8 \\
227 \cdot 6\end{array}$ \\
\hline B & Faeces & $\begin{array}{l}\text { None } \\
300 \mathrm{~g}\end{array}$ & $\begin{array}{l}69^{\circ} 0 \\
62^{\circ} 9\end{array}$ & $\begin{array}{r}r 4 \cdot 6 \\
8.8\end{array}$ & $\begin{array}{l}5 \cdot 7 \\
3.6\end{array}$ & $\begin{array}{r}5 \cdot 5 \\
18 \cdot 3\end{array}$ & $\begin{array}{l}3 \cdot 6 \\
5 \cdot 1\end{array}$ & $\begin{array}{l}x \cdot 6 \\
1 \cdot 3\end{array}$ & $\begin{array}{r}64.8 \\
118.8\end{array}$ \\
\hline
\end{tabular}


infused was calculated to be $\mathrm{I} 6 \mathrm{~g}$ daily, compared with $2 \mathrm{~g}$ daily during the saline infusion period.

Nitrogen. The distribution of nitrogen between the various fractions is given in Table 3. Samples were fractionated when no starch was infused and when $300 \mathrm{~g}$ of starch were infused; additional values are shown for sheep B when given starch orally and when receiving only the basal ration. An increase in nitrogen excretion when starch was infused was apparent both in the bacterial plus endogenous nitrogen

Table 3. Intake and excretion of nitrogen and fractionation of faecal nitrogenous components when two sheep were given daily either a basal diet of $900 \mathrm{~g}$ dry matter of pelleted dried grass or $300 \mathrm{~g}$ of starch via the terminal ileum, and also when one sheep was given $230 \mathrm{~g}$ starch with the basal ration

\begin{tabular}{|c|c|c|c|c|c|c|c|}
\hline Treatment & $\begin{array}{c}\text { Nitrogen } \\
\text { intake } \\
(\mathrm{g} / \mathrm{d})\end{array}$ & $\begin{array}{c}\text { Faecal } \\
\text { nitrogen } \\
(\mathrm{g} / \mathrm{d})\end{array}$ & $\begin{array}{l}\text { Undi- } \\
\text { gested } \\
\text { nitrogen } \\
(\mathrm{g} / \mathrm{d})\end{array}$ & $\begin{array}{l}\text { Bacterial } \\
\text { and } \\
\text { endo- } \\
\text { genous } \\
\text { debris } \\
\text { nitrogen } \\
(\mathrm{g} / \mathrm{d})\end{array}$ & $\begin{array}{l}\text { Water- } \\
\text { soluble } \\
\text { nitrogen } \\
(\mathrm{g} / \mathrm{d})\end{array}$ & $\begin{array}{l}\text { True } \\
\text { digesti- } \\
\text { bility } \\
\text { of } \\
\text { nitrogen } \\
(\%)\end{array}$ & $\begin{array}{c}\text { Apparent } \\
\text { digesti- } \\
\text { bility } \\
\text { of } \\
\text { nitrogen } \\
(\%)\end{array}$ \\
\hline \multicolumn{8}{|l|}{ Sheep A: } \\
\hline No infusion & $19 \cdot 31$ & $5 \cdot 00$ & $0.3^{8}$ & $3 \cdot 20$ & $I \cdot 42$ & $98 \cdot 0$ & $74 \cdot 1$ \\
\hline $300 \mathrm{~g}$ starch infused & $19^{\circ} 3^{1}$ & 9.09 & 0.53 & $4 \cdot 97$ & 3.59 & $97 \cdot 3$ & $52 \cdot 9$ \\
\hline \multicolumn{8}{|l|}{ Sheep B: } \\
\hline No infusion & 19.31 & $6 \cdot 65$ & 0.72 & $3 \cdot 88$ & $2 \cdot 05$ & $96 \cdot 3$ & $65 \cdot 6$ \\
\hline $300 \mathrm{~g}$ starch infused & $19 \cdot 31$ & $9 \cdot 95$ & 0.78 & $5 \cdot 37$ & 3.80 & $96 \cdot 0$ & $48 \cdot 5$ \\
\hline \multicolumn{8}{|l|}{ Sheep B: } \\
\hline No infusion & 19.64 & $6 \cdot 56$ & $\mathbf{I} \cdot 07$ & $3 \cdot 61$ & $x \cdot 88$ & $94 \cdot 6$ & $66 \cdot 6$ \\
\hline $\begin{array}{l}\mathbf{2 3} \mathrm{g} \text { starch given in } \\
\text { feed }\end{array}$ & 19.64 & 7.01 & 0.98 & $4^{\circ} \cdot{ }^{8}$ & $x \cdot 55$ & $95 \cdot 0$ & $64 \cdot 3$ \\
\hline
\end{tabular}

fraction and in the water-soluble fraction. There was little effect on the true digestibility of nitrogen, although the apparent digestibility of nitrogen was markedly reduced when starch was infused. When starch was given in the food to sheep B there was a slight increase in the excretion of faecal nitrogen which seemed to be confined to the bacterial and endogenous fraction.

Microbial examination. When the saline solution containing no starch was infused bacterial counts in the caecal content were $4.5 \times 10^{8} / \mathrm{ml}$ and $3.9 \times 10^{8} / \mathrm{ml}$ for medium M 8 and the starch medium respectively. When $300 \mathrm{~g}$ starch were being infused into the caecum of sheep B, bacterial counts on medium M 8 were $5^{.2} \times 10^{8} / \mathrm{ml}$ and for the starch medium $7 \cdot \mathrm{I} \times 10^{8} / \mathrm{ml}$. Counts on medium M 8 gave a small but probably not a significant increase in numbers of $17 \%$ compared with the corresponding counts on the basal ration; for the starch medium the increase in numbers was considerably higher, being $83 \%$.

The major organisms isolated when starch was infused into the caecum were $(a)$ slender curved Gram-negative rods similar to Butyrivibrio species, (b) chains of Gramnegative cocci, $(c)$ bacteroides-like rods, $(d)$ Gram-positive cocci mostly in pairs, (e) lactobacilli, $(f)$ Gram-positive bifidus-like organisms, and ( $g$ ) Gram-negative crescent-shaped organisms similar to Selenomonas species. A greater variety of bacteria grew on the starch medium than on medium M8. When only the basal ration 
was given there were marked differences in the major organisms growing in the higher dilutions. The slender curved Gram-negative rods (a), chains of Gram-negative cocci $(b)$, and Selenomonas-like species $(g)$ were not found. Lactobacilli $(e)$ were the principal organisms isolated, followed by Gram-negative cocci $(d)$ and bacteroides-like organisms $(c)$; bifidus-like organisms $(f)$ were also present.

Expt 3. The dry-matter and nitrogen intakes and outputs from the one sheep used in Expt 3 are given in Table 4.

Table 4. Intake and excretion of dry matter (DM) and nitrogen and the fractionation of faecal nitrogenous components when sheep $C$ was given pelleted dried grass $(757 \mathrm{~g} \mathrm{DM}$ daily) or received maize starch either orally or infused via the terminal ileum

\begin{tabular}{|c|c|c|c|c|}
\hline Measurement & $\begin{array}{c}\text { Basal } \\
\text { ration + starch } \\
\text { fed }\end{array}$ & Basal ration & $\begin{array}{c}\text { Basal } \\
\text { ration + starch } \\
\text { infused in } \\
\text { terminal } \\
\text { ileum }\end{array}$ & Basal ration \\
\hline Intake of basal diet ( $(\mathrm{g} \mathrm{DM} / \mathrm{d})$ & 757 & 757 & 757 & 757 \\
\hline Addition of starch ( $\mathrm{g} \mathrm{DM} / \mathrm{d})$ & 170 & - & 99 & 0 \\
\hline Faecal DM output $(\mathrm{g} / \mathrm{d})$ & 362 & 305 & 390 & 300 \\
\hline$N$ intake $(g / d)$ & 12.04 & I $2 \cdot 04$ & $12 \cdot 04$ & 12.04 \\
\hline Urinary $N$ excretion $(\mathrm{g} / \mathrm{d})$ & $2 \cdot 39$ & 4.45 & $3 \cdot 89$ & $4 \cdot 11$ \\
\hline Faecal $N$ excretion $(g / d)$ & $7 \cdot 63$ & $7 \cdot 38$ & $7 \cdot 70$ & $6 \cdot 82$ \\
\hline Faecal indigestible $N(\mathrm{~g} / \mathrm{d})$ & 0.75 & $I \cdot 36$ & $\mathrm{r} \cdot 24$ & $I \cdot 26$ \\
\hline $\begin{array}{l}\text { Faecal, bacterial and endo- } \\
\text { genous debris } \mathrm{N}(\mathrm{g} / \mathrm{d})\end{array}$ & $4 \cdot 35$ & $3 \cdot 59$ & $4 \cdot 32$ & $3 \cdot 71$ \\
\hline Faecal water-soluble $N(\mathrm{~g} / \mathrm{d})$ & 2.53 & $2 \cdot 43$ & $2 \cdot 14$ & $I \cdot 85$ \\
\hline True digestibility of $\mathrm{N}(\%)$ & 93.8 & $88 \cdot 7$ & $89 \cdot 7$ & $89 \cdot 6$ \\
\hline
\end{tabular}

Addition of starch to the basal diet caused a small increase in faecal nitrogen which was due to an increase in the bacterial and endogenous nitrogen fraction partly offset by a decrease in the indigestible nitrogen fraction. When starch was infused via the terminal ileum there was a greater increase in the faecal nitrogen excretion due to increases in the bacterial and endogenous fraction and also in the water-soluble fraction.

\section{DISCUSSION}

\section{Comparison of rumen and caecal fermentation}

The effect of diet on the type of caecal fermentation, which was found in Expt I, fully confirmed the observations noted earlier (Ørskov, Fraser \& Kay, r969) and showed that caecal fermentation and rumen fermentation are influenced in a similar manner by consumption of a starch diet. This similarity may perhaps be expected as the degree of anaerobiosis (eH) in caecal contents (Bergeim, Kleinberg \& Kirch, I945) is similar to that in rumen contents (Hobson \& Howard, I969). The proportion of acetic acid in the caecum contents was slightly higher than in the rumen contents. This would be expected since the proportion of starch to fibre was much lower in the substrate present in the caecum than in that in the rumen, though the differences were small and not significant.

It is noteworthy that in the comparison of caecal and rumen fermentation the 
proportions of iso-acids were much greater in the caecal than in the rumen contents. In rumen fluid the molar proportions of isobutyric and isovaleric acids are generally less than $2 \%$, whereas more than $3 \%$ was normally recorded in caecal contents. ElShazly (1952) and Annison (1954) showed that the concentration of iso-acids was particularly associated with extensive degradation of protein. These observations were later confirmed by Cline, Garrigus \& Hatfield (1966) and Ørskov \& Oltjen (1967) who showed that the concentration of iso-acids in the rumen was small when urea was the only source of nitrogen in the diet and rose substantially when soya protein was used. The findings suggest that the degradation of nitrogenous compounds giving rise to iso-acids is very extensive in the caecum. The ammonia formed during this process may either be absorbed or serve as a source of nitrogen for microbial growth when a carbohydrate substrate is being fermented simultaneously in the caecum. Hogan \& Phillipson (1960), Clarke, Ellinger \& Phillipson (1966) and Topps, Kay \& Goodall ( 1968 ) showed that the nitrogen disappearing from the large intestine varied from 0.5 to $2 \mathrm{~g} / \mathrm{d}$, and unpublished work (E. R. Ørskov \& C. Fraser) has shown that 2:2 $\mathrm{g}$ of nitrogen disappeared daily from the large intestine when a barley concentrate was given to sheep.

\section{The effect of infusing starch into the caecum}

In Expt 2 the main effect of infusion of starch into the caecum was to increase the proportion of butyric acid. This again is in agreement with reports on rumen fermentation and with the results of Expt I. Increased administration of starch generally increases the proportion of propionic acid, and in some experiments a population of rumen micro-organisms was established which produced a large proportion of butyric acid (Donefer, Lloyd \& Crampton, I963; Ørskov \& Allen, 1966). These results were also corroborated by the changes which occurred in the caecal microflora where the main changes were in species similar to Butyrivibrio. Fig. 2 shows clearly that the capacity for digestion of starch in the large intestine was limited, because when more than $138 \mathrm{~g}$ were infused most of the additional starch appeared in the faeces. The factors limiting starch fermentation are not known, but apart from the possibility of an inadequate nutrient medium for bacterial development in the caecum, the soft unpelleted nature of the faeces, which resulted when more than $138 \mathrm{~g}$ were infused, may well have resulted in accelerated passage and reduced retention in the large intestine.

The increase in faecal nitrogen excretion that accompanied the infusion of starch, combined with the increases that occurred in the viable count of bacteria in caecal fluid of sheep B, clearly indicates that there was an increase in microbial nitrogen synthesis. This is further substantiated by the fractionation of the faecal nitrogenous components which showed that the increase occurred in the fraction determined as bacterial and endogenous, and in the water-soluble fraction, and not in the undigested dietary nitrogen. The results cannot show whether the nitrogen incorporated into bacterial cells arose from the ammonia formed during protein degradation in the caecum or from an influx of nitrogen from the blood or from both. In both instances the results would be a change in the route of nitrogen excretion from the urine to the 
faeces, and such a trend was observed in Expt 3 . Factors which cause changes in the extent of fermentation, such as particle size and level of feeding (Ørskov, Flatt \& Moe, I 968), may therefore influence the quantity and quality of faecal nitrogen and, further, the nature of the starch may be important. It was, for example, shown by Baker, Nasr Morrice \& Bruce (1950) and Subrahmanyan, Sreenivasamurthy, Krishnamurthy \& Swaminathan (1958) with rats that several starches were incompletely digested in the small intestine and caused increases both in the caecal content and in its microflora. Differences in extent of rumen fermentation of different starches have also been shown (Ørskov, Fraser \& Kay, 1969).

Previous work (Ørskov, Fraser \& Kay, 1969) with sheep showed that under conditions when diets contained $200 \mathrm{~g}$ starch practically no dietary starch escaped fermentation. In the present experiments the increases in faecal nitrogen excretion were much lower when starch was given orally than when it was infused into the caecum. This increase may be associated with microbial material since the increases occurred in the fraction estimated as bacterial and endogenous. The increase was on average for Expts 2 and 3,0.4 $\mathrm{g} \mathrm{N}$ in nitrogenous components of bacterial or endogenous origin per $100 \mathrm{~g}$ starch dry matter ingested.

When raw starch was infused into the caecum in Expt 2 the increase in the BEDN fractions was on average $\mathrm{I} \cdot \mathrm{g} \mathrm{N} / \mathrm{100} \mathrm{g}$ of the starch dry matter which disappeared in the large intestine as estimated by the difference between the amount of starch infused and the amount in the faeces. The value obtained in Expt 3 was lower, but this was likely to be less accurate than the value obtained in Expt 2 since in Expt 3 no attempt was made to terminate possible fermentation in the faeces after excretion. The increases in the water-soluble + bacterial and endogenous fractions in Expt 2 were equivalent to $2.0 \mathrm{~g} \mathrm{~N} / \mathrm{l} 00 \mathrm{~g}$ of starch disappearing in the caecum. In this context it is interesting to note that Hungate (1966) in a review of the literature suggested a range of from 0.9 to $\mathrm{I} \cdot 7 \mathrm{~g}$ microbial $\mathrm{N} / \mathrm{roO} \mathrm{g}$ carbohydrate fermented. While the difference in nitrogen excretion when starch is given by mouth and when it is infused into the caecum is likely to bear some relation to the digestibility of bacterial nitrogen in the small and large intestines, it is not possible from these studies to make any quantitative deductions.

The results show that if large quantities of digestible dietary carbohydrate escape ruminal fermentation and reach the caecum it is not of advantage to the host, because if large quantities are fermented there the absorption of VFA is inefficient and the microbial nitrogen formed is not digested. As suggested earlier (Ørskov, Fraser \& Kay, 1969), this would be of advantage only in species that are coprophagic, which indeed many animal species are where the caecal fermentation is extensive.

We thank Miss Meryl H. Foot for her valuable assistance in part of this work and Mr R. S. Reid for the VFA analysis. We express our gratitude to Dr R. N. B. Kay for providing facilities for part of this work, for surgically preparing the animals and for many helpful discussions. This work was carried out with the technical assistance of Mrs Elizabeth L. Corse, Miss Moira Henry, Mr R. Pirie and Mr G. Milne. 


\section{REFERENCES}

Annison, E. F. (1954). Biochem. F. 57, 400.

Association of Official Agricultural Chemists (x960). Methods of Analysis p. 284. Washington, DC: Association of Official Agricultural Chemists.

Baker, F., Nasr, H., Morrice, F. \& Bruce, J. (1950). F. Path. Bact. 62, 6r 7.

Bergeim, O., Kleinberg, J. \& Kirch, E. R. (1945). F. Bact. 49, 453.

Blaxter, K. L. (1967). The Energy Metabolism of Ruminants 2nd ed. London: Hutchinson.

Clarke, E. M. W., Ellinger, G. M. \& Phillipson, A. T. (1966). Proc. R. Soc. B 166, 63.

Cline, T. R., Garrigus, U. S. \& Hatfield, E. E. (1 966). F. Anim. Sci. 25, 734.

Donefer, E., Lloyd, L. E. \& Crampton, E. W. (1963). J. Anim. Sci. 22, 425.

El-Shazly, K. (1952). Biochem. F. 5I, 647.

Hobson, P. N. \& Howard, B. H. (1969). In Handbuch der Tierernährung Vol. I, p. 207 [W. Lenkeit, K. Breirem and E. Crasemann, editors]. Berlin: Verlag Paul Parey.

Hogan, J. P. \& Phillipson, A. T. (1960). Br. F. Nutr. 14, 147.

Hungate, R. E. (1950). Bact. Rev. r4, I.

Hungate, R. E. (1966). The Rumen and its Microbes. London: Academic Press.

Kurihara, Y., Eadie, J. M., Hobson, P. N. \& Mann, S. O. (1968). F. gen. Microbiol. 51, 267.

MacRae, J. C. \& Armstrong, D. G. (1966). Proc. Nutr. Soc. 25, xxxiii.

Mann, S. O. (1970). F. appl. Bact. 33. (In the Press.)

Mason, V. C. (1969). F. agric. Sci., Camb. 73, 99.

Ørskov, E. R. \& Allen, D. M. (1966). Br. F. Nutr. 20, 519.

Ørskov, E. R., Andrews, R. P. \& Gill, J. C. (1969). Anim. Prod. 11, 187.

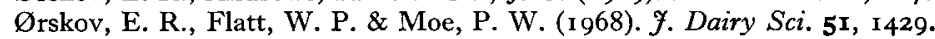

Ørskov, E. R. \& Foot, M. H. (1969). Proc. Nutr. Soc. 28, 3 I $A$.

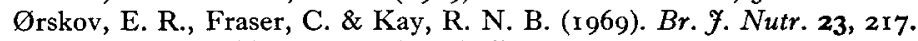

Ørskov, E. R. \& Oltjen R. R. (1967). \%. Nutr. 93, 222.

Rogosa, M., Mitchell, J. A. \& Wiseman, R. F. (I95 I). F. Bact. 62, I32.

Subrahmanyan, V., Sreenivasamurthy, V., Krishnamurthy, K. \& Swaminathan, M. (1958). Ann. Biochem. exp. Med. x8, I 17.

Sutherland, T. M., Gupta, B. N., Reid, R. S. \& Murray, M. G. (1963). Proc. int. Congr. Nutr. vi. Edinburgh p. 579.

Topps, J. H., Kay, R. N. B. \& Goodall, E. D. (I968). Br. F. Nutr. 22, 26 r.

Van Soest, P. J. (1963). F. Ass. off. agric. Chem. 46, 829.

Wiseman, G. (1968). In Handbook of Physiology. Sect. 6. Alimentary Canal Vol. 3 [C. F. Code and W. Heidel, editors]. Washington, DC: American Physiological Society. 